\title{
Kognitív tudományok az ítélkezési tevékenység szolgálatában
}

\author{
Cognitive Sciences and Judicial Decision-Making
}

\begin{abstract}
ABSZTRAKT
Napjainkra meghaladottá vált az a nézet, hogy a bírák csak jogszolgáltatást végeznének. Alapvető elvárás, hogy a „jó bíró” számtalan olyan készséggel, képességgel rendelkezzen, amelyek megszerzéséhez és fejlesztéséhez nem a jogtudomány nyújt majd segítséget. Ha elfogadjuk, hogy „a bírák is emberek”, el kell fogadnunk azt is, hogy elméjükre és döntéshozatali folyamataikra is az általánosan elfogadott tudományos törvényszerüségek vonatkoznak. A kognitív tudományok robbanásszerüen felkapott eredményei kevésbé ismertek hazánkban, pedig ezek segítségével az ítélkezés szubjektív elemei tovább csökkenthetők, a tudatosság pedig pontosabb döntések meghozatalához vezethet.
\end{abstract}

Kulcsszavak: Jog és pszichológia, kognitív tudomány, idegtudomány, neurojog, heurisztikák és torzitások, bírói döntéshozatal

\begin{abstract}
Nowadays, judges are expected not just to administer justice, but to have skills and abilities to realize and be aware of standards and laws which can be discovered and analysed by the so called cognitive sciences. In case we accept that "judges are human beings as well," we must also assume that their minds and decision-making processes are subject to generally accepted scientific facts. However, cognitive sciences are less known in Hungary, using their fruitful results in legal procedures (e. g. in court trials) a greater level of objectivity can be achieved in adjudication which can lead to more accurate judicial decisions.
\end{abstract}

Keywords: law and psichology, cognitive science, neuroscience, neurolaw, heuristics and biases, judicial decision-making

Az emberi viselkedés tanulmányozásakor a múlt és a jelen képes ajtót nyitni a jövőre vonatkozó következtetések számára. Ez azt jelenti, hogy képesek lehetünk következtetéseket levonni abból, amit az emberek döntéseiről és cselekedeteiről tudunk, és javaslatokkal élhetünk a fennálló jogszabályi környezet és a jogalkalmazói attitűd megújítása érdekében. Tekintettel arra, hogy a bírósági ítéletek is emberi cselekedetek és döntéshozatali folyamatok eredményeként születnek, a döntéshozatalra vonatkozó általános ismeretek ítélkezési tevékenységre vetítése magában hordozza az ismeretek bővítésének és a bírói döntéshozatal szubjektív elemei

* Dr. Gábri Angéla, PhD-hallgató, Debreceni Egyetem Marton Géza Állam- és Jogtudományi Doktori Iskola, Jogbölcseleti és Jogszociológiai Tanszék, e-mail: gabriangela92@gmail.com. A tanulmány megjelenését az EFOP-3.6.1-16-2016-00022 Debrecen Venture Catapult Program című pályázat tette lehetővé. 
szükítésének lehetőségét. Napjainkra meghaladottá vált az a nézet, hogy a bírák csak jogszolgáltatást végeznek. Alapvető elvárás, hogy a „jó bíró” számtalan olyan készséggel, képességgel rendelkezzen, amelyek megszerzéséhez és fejlesztéséhez nem a jogtudomány nyújt segítséget. Így lehetséges az, hogy a bírósági szervezet olyan interdiszciplináris kutatási területek eredményeit használja fel a mindennapi jogalkalmazásban, mint például a jog és nyelv kapcsolata (így a közérthetőség témaköre), az informatika (digitalizált igazságszolgáltatás), de akár az új generációhoz tartozó bírák, titkárok és bírósági fogalmazók oktatási reformjai mögött is több tudományterület (pedagógia, pszichológia) fedezhető fel.

Ugyanígy nyújthatnak segítséget a kognitív tudományok is, amelyek a döntéshozatalról kialakult képet árnyalják. Minél több tudással rendelkezik a jogásztársadaIom a kognitív tudományok által feltárt törvényszerüségekröl, annál inkább biztosítható a pontosabb, torzításmentes döntéshozatal, így például a bizonyítás eredményének helyes alapokon nyugvó értékelése is. A kognitív tudományok eredményei az ítélkezés minőségét a fenti célok érdekében hivatottak javítani, ehhez azonban először érdemes megismerni ezt a határterületet, amely a hazai kutatók által még kevésbé dokumentált, azonban a virágzó angol nyelvű irodalomból megismerhető.

Magának az interdiszciplináris megközelítésnek a büntető ítélkezési tevékenység során történő hasznosíthatóságának jelentőségére számos jogtudományi kutatás világított már rá. ${ }^{1}$ Ezek közül azonban csak néhány utal kifejezetten a pszichológia által nyújtott lehetőségekre:

A bírói belső meggyőződés, amit a büntetőeljárási törvény mérceként elöír, olyan pszichológiai tényezők alapján alakul ki, amelyeknek az ismerete tudatosabbá teheti a vallomások megszerzését és értékelését. ${ }^{2}$...A bírói meggyőződés megismeréséhez indokolt az emberi gondolkodást, a pszichét tanulmányozni. ${ }^{3}$

Arra, hogy számtalan lehetőség rejlik az interdiszciplináris megközelítésben, a Hunyady György és Berkics Mihály szerkesztésében megjelent, „A jog szociálpszichológiája: $A$ hiányzó láncszem" címü tanulmánykötet is rávilágít, ${ }^{4}$ amely a jogtudomány és az emberi viselkedést kutató tudományok (mint a pszichológia, szociálpszichológia, neuropszichológia) izgalmas kapcsolódási pontjait járja körül. Ugyan a kötetnek nem feladata kifejezetten a bírói döntéshozatal vizsgálata, de utalásokat lehet találni benne arra, hogy a pszichológia bölcsességével kiküszöbölhetőek az

\footnotetext{
1 VINNAI Edina: Jog és nyelv határán - a jogi nyelvhasználat nemzetközi és hazai kutatása. Budapest, Gondolat Kiadó, 2017.; ELEK Balázs: A vallomás befolyásolása a büntetőeljárásban. Debrecen, TKK, 2008.; BENCZE Mátyás: „Nincs füst, ahol nincsen tüz” - az ártatlanság vélelmének érvényesülése a magyar bírói gyakorlatban. Gondolat, Budapest, 2016.

2 ELEK Balázs: A téves ténymegállapitás egyes pszichológiai aspektusai. Debreceni Jogi Mühely, 2006/4. http://www.debrecenijogimuhely.hu/archivum/4_2006/a_teves_tenymegallapitas_egyes_pszichologiai_aspektusai/ (2020. 04. 26.).

${ }^{3}$ HÁGER Tamás: Dilemmák a bírói meggyőződésröl, figyelemmel az új büntetőeljárási törvény koncepcionális változásaira. Jogtudományi Közlöny, 2019/10, 406.

${ }^{4}$ Hunyady György-Berkics Mihály (szerk.): A jog szociálpszichológiája - A hiányzó láncszem. ELTE Eötvös Kiadó, Budapest, 2015.
} 
elfogultsághoz hasonló negatív hatások, így a reflektálatlan tudati mechanizmusok szerepe a döntéshozatal során lecsökkenthetö a szükséges mértékre. ${ }^{5}$

Mindemellett a Kúria Joggyakorlat-elemző Csoportja 2017-ben összefoglaló véleményt készített az ítéleti bizonyosság elméleti és gyakorlati kérdéseiröl. A véleményben célszerünek tartják a pszichológiában rejlő lehetőségek széles körben történő alkalmazását. Ennek megvalósítása érdekében konkrét javaslatként szerepel, hogy

...első lépésként indokoltnak látszana egy rövid oktatási anyag összeállitása, amely kifejezetten a bírói munka sajátosságaihoz és szükségleteihez igazodva, közérthető módon összefoglalja az e tevékenységgel összefüggő és annak során leginkább hasznosítható pszichológiai ismereteket. Ezt követően oktatások, vagy konzultációk szervezésével lehetne elősegíteni ezek elsajátítását. ${ }^{6}$

E tanulmánnyal ehhez a célhoz kívánok hozzájárulni, így a kutatási eredmények népszerüsítése érdekében bemutatom egyrészt a kognitív idegtudomány és a jogi döntéshozatal kapcsolatát, másrészt egy hasonlóan innovatív, a bírói döntéshozatalt új perspektívából megvilágító kognitív pszichológiai területet, amely nemcsak a mindennapi életben meghozott döntések, de az itélethozatal tudatosságát is képes fejleszteni.

\section{A kognitív tudományok (megismeréstudományok)}

A kognitív tudomány (angolul cognitive science) egy összefoglaló elnevezés, épp ezért többes számú alakja (kognitív tudományok, franciául sciences cognitives) pontosabb képet fest definíciójáról. ${ }^{7}$ Maga a kognitív jelző az emberi gondolkodásra, a megismerésre (kognícióra) utal, ${ }^{8}$ ugyanis a megismeréssel foglalkozó tudományokat kapcsolja össze: ilyen az elméleti számítástudomány, a matematika, a logika, a filozófia, a biológia, valamint a pszichológia, amellyel a legszorosabb kapcsolatban áll. ${ }^{9}$ Kérdésként merülhet fel, hogy amennyiben a felsorolt tudományok gyüjtőfogalmáról van szó, miért vált „új” és önálló tudományterületként ismertté. Válaszként szolgálhat annak hangsúlyozása, hogy nem egy tudományterületről van szó, sokkal inkább egy tudományos szemléletröl, amely nemcsak a kifejezetten megismeréstudományként felsorolt, hanem számos más tudományra is hatással van. Így például az antropológiára, a mesterséges intelligenciára, a nyelvészetre vagy az idegtudományra. Pléh emiatt amellett foglal állást, hogy egy „életlen határokkal jellemezhető attitüdröl vagy hozzáállásról van szó”, mely nem feleltethető meg külön-külön egyik jellemző

\footnotetext{
${ }^{5}$ GÁBRI Angéla: A jog szociálpszichológiája - A hiányzó láncszem (recenzió). Pro Futuro, 2017/1, 158.

${ }^{6}$ Kúria Büntető-Közigazgatási-Munkaügyi és Polgári Kollégiumai Joggyakorlat-Elemző Csoport: Összefoglaló vélemény - Az ítéleti bizonyosság elméleti és gyakorlati kérdései. Budapest, 2017, 28. https://kuria-birosag. hu/sites/default/files/joggyak/osszefogl_velemeny_iteleti_bizonyossag.pdf (2020. 04. 27.).

7 PLÉH Csaba: Bevezetés a megismeréstudományba. Elektronikus Kiadó, Budapest, 1998, 11.

8 PLÉH (1998): i. m., 19.

9 PLÉH (1998): i. m., 11.
} 
attitüdjének sem. ${ }^{10}$ Nem egy új tudományról van tehát szó, hanem a diszciplínák közötti együttmüködésről, az egyes területeken túllépő szemléletről. ${ }^{11} \mathrm{E}$ szemlélet azonban önálló, amelynek magyarázata a kialakulását megelőző, behaviorista felfogásban és a pszichológia történetében gyökerezik.

A kognitív hozzáállás az 1950-es évek végén, a '60-as évek elején fejlödött ki, amelyet kognitív forradalomként is aposztrofálnak. ${ }^{12} \mathrm{E}$ mozgalom két szakaszban bontakozott ki: az első a kognitív pszichológia, a második a kognitív tudomány forradalma. ${ }^{13}$

A kognitív pszichológia az ötvenes években uralkodó viselkedéstudományi (behaviorista) felfogást váltotta fel, ugyanis sokkal nagyobb hangsúlyt fektetett arra, hogy mi van az ember fejében, így a viselkedésre már nem úgy tekintett, mint amelyet kizárólag fizikai ingerek befolyásolhatnak. ${ }^{14}$ Egyre inkább a gondolkodásra kezdett koncentrálni, ez a folyamat pedig a '40-es évek végén megjelent információelméletnek és kibernetikának köszönhetö. ${ }^{15} \mathrm{~A}$ második világháború katonai kutatásaihoz ugyanis elengedhetetlen volt a megfejthetetlen kódok létrehozása és különböző kommunikációs csatornákon történő célba juttatása, valamint a gépek szabályozása. A két szemlélet hozadékának tekinthetők az általánosan elfogadott matematikai elméletek, amelyek következtében elképzelhetővé vált, hogy az ember is bonyolult információfeldolgozó és szabályozó rendszerrel rendelkezik, amely leírható különböző modellekkel. ${ }^{16}$ Így került kapcsolatba a kognitív pszichológia a logikával és a gépek müködésével alkotott párhuzam miatt a filozófiával, majd a mesterséges intelligencia volt az, amely a '70-es években a megismeréstudományok felé vezette a kognitív forradalmat. ${ }^{17}$ Ez tekinthető a második forradalomnak. Így került a kognitív pszichológia „belső szemlélete” kapcsolatba számos más tudománnyal, és azokra egy máig jellemző, erőteljes hatást gyakorolt. Ezt követően alakult ki a kognitív antropológia és szociológia, melyek a társadalmat is modellálási kérdésként kezdték felfogni, valamint a kognitív nyelvészet (középpontja a nyelv és megismerés) és kognitív etológia (fajok viselkedésének modelláló megfigyelése).$^{18}$ Mindegyik tudományban közös, hogy a megismerést egy reprezentációs rendszerként képzelik el, a kogníció szó jelentése pedig a szimbólumok átalakítása, ahol a műveletek szabályjellegűek és pusztán a szimbólumok formáján alapulnak. ${ }^{19}$

A fentiekből adódóan magára a kognitív tudományra a következő megállapításokat lehet tenni: egyrészt az ismeret, tudás reprezentációjával, változásával és formális jellemzésével foglalkozik, másrészt több tudomány szemléletmódjából fejlödött ki, amelyek metszete a pszichológia. ${ }^{20}$

\footnotetext{
${ }^{10}$ PLÉH (1998): i. m., 14.

11 PLÉH (1998): i. m., 15.

12 PléH (1998): i. m., 29.

${ }^{13}$ PLÉH Csaba: A modern kognitivizmus mozgalma és változásai. In: Pléh Csaba (szerk.): Kognitív tudomány. Osiris, Budapest, 1996, 9.

14 PlÉH (1996): i. m., 10-11.

15 PlÉH (1998): i. m., 29.

16 PlÉH (1998): i. m., 39.

17 PléH (1996): i. m., 11.

${ }^{18}$ PLÉH (1998): i. m., 44-45.

19 PLÉH (1996): i. m., 14.

${ }^{20}$ PLÉH (1996): i. m., 13.
} 
E tanulmány a kognitív tudományok közül a büntetöjogászok által hasznosnak talált „modern pszichológia” ${ }^{21}$ eredményeinek feltárása céljából a kognitív döntéspszichológia és kognitív idegtudomány bemutatására vállalkozik.

A kognitív döntéspszichológia bemutatása azért fontos, mert az ítéletalkotás, azon belül minden egyes eljárásjogi döntés, a bizonyítékok értékelése, azok kizárása, a bírói meggyőződés mint a bizonyosság mércéje mind-mind a bíró elméjében lejátszódó folyamatok. Az emberi gondolkodásra és viselkedésre vonatkozó sémák megismerése a tanúk által elmondottak minél pontosabb értékelésében, de akár az ő gondolkodásmódjuk, vagy annak korlátai megértésében is hasznos segítséget jelenthet.

A kognitív idegtudomány célja a magasabb kognitív funkciók neurobiológiai alapjának megértése. ${ }^{22}$ Bemutatása azért bír jelentőséggel, mert az emberi agy felépítése és működése alapján kutatja a viselkedés alapjául szolgáló mentális folyamatokat, amelyek minél teljesebb megértése a jogi döntéshozatal szempontjából rendkívül fontos. ${ }^{23}$

\section{A kognitív idegtudomány és az ítélkezési tevékenység kapcsolata}

A kognitív idegtudomány a fentiekben leírtaknak megfelelően az emberi agy múködését, annak az elmebeli sajátosságokra való kihatását kutatja. Önmagában a kognitív tudományok kutatási területe az 1950-es években, a Harvardon jelent meg, és nagyon gyorsan kezdett terjedni, különösen azt követően, amikor Noam Chomsky nyelvész munkája nyomán George Miller elkezdte az emberi nyelvröl tanultaknak egy új kutatási területen (pszicholingvisztika) való alkalmazhatóságát vizsgálni. ${ }^{24}$ Az 1980-as évek elején még gyerekcipöben járt az arra vonatkozó gondolkodás, hogy miként jelennek meg a komplex mentális reprezentációk az idegrendszerben. A fejlődést az hozta meg, amikor a kísérleti pszichológia szakított régi, szigorú nézeteivel és azzal az elmélettel, hogy mindent meg lehet magyarázni a magatartáselmélet kifejezéseivel. A saját dinamikával és saját szabályrendszerrel bíró kognitív nézetek ekkor nőttek túl a pszichológián. ${ }^{25} \mathrm{Az}$ idegtudományok képviselői azonban ekkor még nem tudták, hogy az általuk vizsgált jelenségeket a kognitív tudományokkal ötvözve is lehet vizsgálni.

A tudományos életben a 80 -as évek nagy változásokat hoztak. Biológiai szempontokból kiinduló pszichológusok - mint Posner, Kosslyn, Hillyard és sokan mások kezdték el vizsgálni, hogyan lehet jobban megérteni az emberi figyelmet, a mentális

\footnotetext{
${ }^{21}$ HÁGER Tamás: A bírói meggyőződés, szubjektív elemek a büntető ítélkezésben. Jura, 2014/2, 74.

22 PLÉH Csaba-GulyÁs Balázs: Mitől kognitív és mitől idegtudomány? In: Pléh Csaba-Kovács Gyula-Gulyás Balázs (szerk.): Kognitív idegtudomány. Osiris, Budapest, 2003, 19.

${ }^{23}$ Petoft, Arian: Neurolaw: A Brief Introduction. Iranian Journal of Neurobiology, 2015/14, 53. https://www. researchgate.net/publication/275046866_Neurolaw_A_brief_introduction (2020.05. 09.).

${ }^{24}$ GazZANIGA, Michael S.: What is Cognitive Neuroscience? In: Jed Rakoff (szerk.): A Judge's Guide to Neuroscience: a Concise Introduction. University of California, Santa Barbara, 2010, 2. https://www.sagecenter.ucsb.edu/sites/ staging.sagecenter.ucsb.edu/files/file-and-multimedia/A_Judges_Guide_to_Neuroscience\%5Bsample\%5D.pdf (2020. 03. 30.).

25 Gazzaniga: i. m., 3.
} 
képeket az agyi folyamatok alaposabb szemügyre vétele nyomán. ${ }^{26}$ Épphogy elkezdett összeérni az idegtudomány és a kognitív tudomány területe, hirtelen megjelent a színen az agyi képalkotás, így az emberi agy annak müködése közben is alapos vizsgálat alá vonhatóvá vált - már nemcsak az észlelés alapvető kérdései, de a magasabb szintủ mentális tevékenységek szempontjából is. ${ }^{27}$

Az elmúlt két évtized alatt a tudományterület az agyi képalkotás olyan módszereivel bővült tovább, amelyek a jogalkalmazás számára különösen fontos mentális állapotok feltárására irányulnak. Így például az agyi képalkotás technológiái segítséget nyújthatnak a bíróságnak, hogy eldöntse, valakinek szándékában állt-e egy cselekmény elkövetése, vagy csak a körülmények áldozata lett, amikor cselekedett. Vannak ugyanis olyan területei az agynak, amelyek a cselekvési szándék kialakításáért felelnek. Az idegtudományok által megfigyelhetővé vált, hogy valaki, aki agyának e területén szenved sérülést, képtelenné válik szándék kialakítására, ez pedig magyarázhatja azt is, ha nincs bủntudata sem. ${ }^{28} \mathrm{~A}$ szándék, a felelősség kérdésének meghatározásában nyújtott orvosi képalkotó diagnosztikai segítség mind polgári eljárásjogi, mind büntető-eljárásjogi szempontból hasznos tudást nyújthat. Büntetőeljárás során például az áldozat idegrendszerében bekövetkezett sérülés feltérképezése történik, amelynek eredménye igen fontos bizonyíték. A sérülések és azok következményeinek megállapítására a leggyakrabban alkalmazott, hagyományos képalkotó módszereket alkalmazzák, mint a CT, a röntgen, az MRI, valamint az elektroenkefalográf és az agy SPECT szkennelése is előfordul. ${ }^{29}$ Vannak azonban olyan új, izgalmas területei ennek a tudománynak, amelyek próbálnak minél konkrétabb, kifejezetten a tárgyalóteremben használható elmebeli sajátosságokat feltárni, nem csupán a sértett, de akár az elkövető vagy a tanúk agymüködése vonatkozásában is.

\subsection{Az idegtudomány a jogban („,neurojog”)}

Az idegtudomány és jog kapcsolata (neurolaw) egy nagyon gyorsan fejlődő interdiszciplináris kutatási terület, amely az idegtudomány jogi területen, különösen a büntetőjogban történő hasznosíthatóságával foglalkozik. ${ }^{30} \mathrm{~A}$ büntetőjog gyakran foglalkozik az egyének, különösen a vádlottak, fogvatartottak, tanúk mentális állapotával. A bíráknak a büntetőjogi fökérdésben való állásfoglalás mellett számos további, külön-külön ugyanolyan fontos kérdésre kell választ találniuk: A vádlott szenved-e valamilyen mentális zavarban, betegségben? Teljes mértékben hiányzik a beszámítási

${ }^{26}$ Gazzaniga: i. m., 3.

27 GaZZANIGA: i. m., 3.

28 GAZZANIGA: i. m., 4.

${ }^{29}$ GRAfton, Scott T.: Has Neuroscience Already Appeared in the Courtroom? In: Jed Rakoff (szerk.): A Judge's Guide to Neuroscience: a Concise Introduction. University of California, Santa Barbara, 2010, 54. https:// www.sagecenter.ucsb.edu/sites/staging.sagecenter.ucsb.edu/files/file-and-multimedia/A_Judges_Guide_ to_Neuroscience\%5Bsample\%5D.pdf (2020. 03. 30.).

${ }^{30}$ MEYNEN, Gerben: Neurolaw: Recognizing Opportunities and Challenges for Psychiatry. Journal of Psychiatry \& Neuroscience, 2016/1, 3. (DOI: 10.1503/jpn.150317). 
képessége, vagy sem, büntethetö-e? Az adott fogvatartott esetében milyen mértékủ a bủnismétlés veszélye? Mire emlékszik ténylegesen a tanú - vajon hazudik-e ? $^{31}$

E lehetőségek kutatása fontos kérdése az idegtudományi jognak. Sajnálatos módon az idegtudomány adta lehetőségekben számos bizonytalansági faktor rejlik, tekintettel arra, hogy minden agy más és más, valamint számos tényező okozhatja az agy szkennelése során felfedezett, egyes szituációkban bekövetkező elváltozásokat. A másik probléma pedig, hogy a mentális jelenségek és az agy müködése közötti összefüggés empirikus úton nagyon nehezen bizonyítható. ${ }^{32}$ Ezt a jelenséget a szakirodalom ${ }^{33}$ „mereológiai tévedésnek” nevezi: „egyszerüen hiba mentális állapotokat tulajdonítani az agy vagy akár az elme egy bizonyos részének" ${ }^{34}$ Azonban sokan bizakodóak, akik szerint nem feltétlen kell beazonosítani ezeket a területeket, elegendő lehet csak a változásokat megfigyelni az egyes kérdésekre adott válaszok során. Így például annak ellenére, hogy még a poligráf használata is elég ellentmondásos (és az agy-alapú változata valószínüleg szintén hatalmas vita tárgyává válik), nagy ütemben fejlődő üzletág az agy feltérképezését végző szkennerek segítségével működő hazugságvizsgáló gépek kialakítása. Ezek abban különböznek a poligráftól, hogy míg a poligráf az egyes kérdésekre a vegetatív idegrendszer által leadott testi reakciókat veszi szemügyre, addig a modern idegtudomány által kifejlesztett technológia kifejezetten az agy válaszadás során történő müködését, annak változásait vizsgálja. ${ }^{35}$

Jelenleg két hazugságvizsgáló technológia támaszkodik az agyi képalkotásra, bár mindkettő hozzáadott értékét és pontosságát élesen vitatják. Az elsőt, amelyet Farwell fejlesztett ki az 1980-as években, „agyi ujjlenyomatnak” is nevezik. Az alanyok elektródával töltött sisakot vesznek fel, amely méri a p300 nevű agyhullámot, amely Farwell szerint megváltoztatja frekvenciáját, amikor az emberek ismerős képeket, alakzatokat, helyszíneket és szagokat érzékelnek. ${ }^{36}$ Danahar azok közé a szerzők közé tartozik, akik szerint a módszer megbízhatósága empirikus kutatások alapján a leginkább alátámasztott. ${ }^{37}$ Megfontolásra bocsátja, hogy hagyományosan egy tanú vagy a vádlott szavahihetőségének vizsgálatára csupán a bíró, vagy a tárgyalást megelőző szakban az ügyész hivatott, így jelenleg nehezebben ellenőriz-

${ }^{31}$ MeYnen: i. m., 3.

32 Montague, Read: How is Neuroscience likely to Impact Law in the Near Future? In: Jed Rakoff (szerk.): A Judge's Guide to Neuroscience: a Concise Introduction. University of California, Santa Barbara, 2010, 60. https:// www.sagecenter.ucsb.edu/sites/staging.sagecenter.ucsb.edu/files/file-and-multimedia/A_Judges_Guide_ to_Neuroscience\%5Bsample\%5D.pdf (2020. 04. 02.).

${ }^{33}$ A témában lásd: MAXWELL, Bennett R.-HAcker, Peter M. S.: Philosophical Foundations of Neuroscience. Oxford, Blackwell, 2003. és PARdo, Michael S.-PATterson, Dennis: Minds, Brains and Law: The Conceptual Foundations of Law and Neuroscience, Oxford University Press, New York, 2013.

${ }^{34}$ HoRvÁtH Lajos: A neurofenomenológia és a megtestesült elme. Transzdiszciplináris dialógus az idegtudomány és a fenomenológia között. http://www.matud.iif.hu/2011/11/03.htm (2020. 04. 03.).

35 DANAHER, John: Brain-Based Lie Detection and the Mereological Fallacy: Reasons for Optimism. In: DonNELLYLAZAROV, Bebhinn (szerk.): Neurolaw and Responsibility for Action: Concepts, Crimes, and Courts. Cambridge University Press, Cambridge, 2018, 163. (DOI: 10.1017/9781108553339.008).

${ }^{36}$ RosEN, Jeffrey: The Brain on the Stand. https://www.nytimes.com/2007/03/11/magazine/11Neurolaw.t.html (2020. 04. 03.).

${ }^{37}$ DANAHER: i. m., 160. 
hető ennek a vizsgálatnak az eredményessége, föleg, ha figyelembe vesszük a tanúk, vádlottak lelki állapotát és pszichológiai befolyásoltságukat. ${ }^{38}$ Rakoff kutatását idézve ${ }^{39}$ hivatkozik arra, hogy az Amerikai Egyesült Államokban végzett empirikus vizsgálatok szerint a vádalkut kötött terheltek 10\%-a ártatlannak bizonyul, kisebb ügyekben annyira erős bennük ugyanis a tárgyalás (és esetleges bünösnek ítélésük esetén a súlyosabb büntetés) elkerülésének vágya, hogy inkább beismerő vallomást tesznek az enyhébb büntetés érdekében ${ }^{40}$ Költség-haszon elemzést végezve, az ártatlanul tett beismerő vallomások elkerülése akkora haszon, amelynek jelentősen növelnie kell a technológia alkalmazhatóságába vetett bizalmat. ${ }^{41}$

A második hazugságvizsgáló technológia a funkcionális mágneses rezonancia képalkotáson (fMRI) és annak gépein alapszik, amelyek összehasonlítják egy személy agyi aktivitását, amikor hazudik, azzal, amikor igazat mond. Ez egy „Guilty Knowledge" nevű tesztre épül, amelyet Langleben fejlesztett ki a Pennsylvaniai Egyetemen 2001-ben. ${ }^{42}$ Langleben az alanyoknak a mágnesbe lépés előtt adott egy játékkártyát, és azt mondta nekik, hogy válaszoljanak nemmel egy sor kérdésre, beleértve azt is, hogy náluk van-e a szóban forgó kártya. Langleben és kollégái felfedezték, hogy az agy bizonyos területei világítanak a monitoron, amikor az emberek hazudnak, és azt mondják, nincs náluk az adott kártyalap. ${ }^{43}$ Neil Feigenson meglehetösen optimista a fMRI bírósági felhasználását tekintve, szerinte fontos a rendelkezésre áló legjobb tudományos eredményekre támaszkodni. ${ }^{44}$

Két társaság, a "No Lie MRl” és a "Cephos Corporation" versenybe szálltak az fMRI hazugságvizsgáló technológia fejlesztése során, hogy lehetővé váljon az általa szolgáltatott információ bizonyítékként történő elfogadása, és hogy egyáltalán kereskedelmi forgalomba tudják azt hozni. A Cephos igazgatója, Steve Laken úgy véli, hogy a laboratóriumi vizsgálatokban a pontosság 80-90\%-os tartományába kerültek. ${ }^{45}$ Ez hasonló a poligráf pontosságához, amelyet azonban nem tartanak kellően megbízhatónak ahhoz, hogy az ügyekben elfogadható bizonyítékot szolgáltasson. Laken abban bízik, hogy eléri a 90-95\%-os pontosságot, aminek elég magasnak kell lennie ahhoz, hogy átmenjen a Legfelsőbb Bíróság tudományos bizonyítékok befogadhatóságának szürőjén. A hazugságvizsgáló fMRI bíróságon való elfogadásának esete számos kérdést vet fel azonban az önvádra kötelezés tilalma és a magánélet tiszteletben tartásának elvével kapcsolatban, sőt, a gondolatszabadság kérdését is feszegeti, ${ }^{46}$ mégis kifejezetten érdekes jövőbe mutató elképzelés, ezért nem feltétlen kell elvetni alkalmazhatóságát, csupán finomítani szükséges módszereit,

38 DANAHER: i. m., 180.

39 RAKoff, Jed: Why Innocent People Plead Guilty. New York Review of Books, 2014. https://www.nybooks.com/ articles/2014/11/20/why-innocent-people-plead-guilty/ (2020. 04. 07.).

40 DANAHER: i. m., 180.

41 DANAHER: i. m., 181.

${ }^{42}$ ROSEN: i. m.

${ }^{43}$ ROSEN: i. m.

44 FREEMAN, Michael: Introduction: Law and Neuroscience. Cambridge University Press, 2006, 1. (DOI: 10.1017/ S1744552306003016).

45 Rosen: i. m.

46 Rosen: i. m. 
ami idő kérdése, és nagyrészt a tudományon múlik. Molnár András pozitívan tekint az idegtudomány által felvetett ehhez hasonló kérdésekre, szerinte „az agykutatás újabb és újabb fejleményeinek jogra gyakorolt hatását érdemesebb az egyéni autonómiának, a szabad akaratnak, valamint ezek korlátainak meghatározására irányuló évezredes törekvések újabb fejleményeként értékelni". 47

Figyelembe véve az idegtudomány egyre nagyobb térhódítását és azt, hogy a bíróságon egyre gyakrabban jelenik meg a felhasználásával keletkezett bizonyíték, létrejött egy hálózat, a MacArthur Alapítvány (Jog és Idegtudományi Kutatási Hálózat), amely az idegtudomány, pszichológia, pszichiátria jeles képviselőiből és jogászokból, így bírákból, ügyvédekből, ügyészekből és jogtudósokból áll. ${ }^{48}$ Céljuk kettős: egyrészt, hogy a jogrendszert megóvják az idegtudomány téves alkalmazásától, másrészt, hogy felfedezzék az idegtudomány azon eredményeit, amelyek a büntető igazságszolgáltatás megbízhatóságát, tisztességességét, objektivitását és hatékonyságát növelik. ${ }^{49} \mathrm{Az}$ Alapítvány megállapításai szerint az fMRI-n alapuló bizonyíték bíróságon való elfogadása még azért várat magára, mert egy csoportra vonatkozóan levont következtetések nem feltétlen alkalmazhatóak az egyénre nézve, továbbá a laboratóriumi vizsgálat ritkán tükrözi a valós környezetet, ráadásul a tényleges eredményességét nagyon nehéz ellenőrizni. ${ }^{50}$ Az utóbbi indokkal utasította el 2012 augusztusában a marylandi Eric M. Johnson bíró a State v. Gary Smith emberölési ügyben benyújtott fMRI-alapú bizonyítékot. ${ }^{51}$ Ugyanez történt a United States $v$. Semrau ügyben 2012 szeptemberében, amelyben azonban tanúként hallgatták meg a már említett Cephos Corporation igazgatóját, Steve Laken-t, aki a vádlott által adott válaszok igaz vagy hamis voltát illetően a „bizonyosan valószínü” kifejezést használta. ${ }^{52}$ Fontos azonban megjegyezni, hogy a bizonyítékok jövőbeli elfogadhatóságának lehetőségét egyik bíróság sem zárta ki, azt a tudomány állásának megfelelően a jövőben ismételten vizsgálat tárgyává lehet tenni. ${ }^{53}$

Az idegtudomány térhódításának realitását vizsgáló szakirodalmi álláspontok rendkívül megosztottak. Egymást váltják a bizakodó és az azokra reagáló pesszimista elképzelések a neurojog tárgyalótermi hasznosíthatóságát illetően. Ezekből kiemelkedik Danahar tanulmánya, amely a kritikai szemléletet alkalmazva vezeti le a neurojog alkalmazhatóságának lehetséges módjait. Pardo és Patterson szkepticiz-

47 MoLNÁR András: Jogelmélet a tudományos innováció fényében: a ,jog és idegtudomány” kutatások és a jog emberképe. Jogelméleti Szemle, 2019/1, 77.

${ }^{48}$ Az Alapítvány tagjairól, célkitűzéseiről és megjelent publikációiról a következő linken érhető el bővebb információ: https://www.lawneuro.org/publications.php.

${ }^{49}$ MacArthur Foundation Research Network on Law and Neuroscience: Network Overview, 2013. https://www. lawneuro.org/networkoverview.pdf (2020. 04. 07.).

${ }^{50}$ MacArthur Foundation Research Network on Law and Neuroscience: fMRI and Lie Detection, 2016. https:// www.lawneuro.org/LieDetect.pdf (2020. 04. 07.).

${ }^{51}$ MacArthur Foundation Research Network on Law and Neuroscience: fMRI and Lie Detection, 2016. https:// www.lawneuro.org/LieDetect.pdf (2020. 04. 07.).

52 United States Court of Appeals: United States v. Semrau, 12. https://cases.justia.com/federal/appellate-courts/ ca6/11-5396/11-5396-2012-09-07.pdf?ts=1411025836 (2020. 04. 08.).

53 United States Court of Appeals: United States v. Semrau, 19. https://cases.justia.com/federal/appellate-courts/ ca6/11-5396/11-5396-2012-09-07.pdf?ts=1411025836 (2020. 04. 08.). 
musát ${ }^{54}$ az agyalapú hazugságvizsgáló technológia vonatkozásában és az ehhez kapcsolódó, mereológiai tévedésen alapuló kritikájukat három érv mentén veti el. Ezek közül az első, hogy az elmélet túlságosan is az fMRI hazugságvizsgálókra koncentrál, így kevésbé foglalkozik a sokkal megbízhatóbb és empirikusan alátámasztott p300 agyhullám alapú hazugságvizsgáló technológiák eredményeivel. ${ }^{55}$ A második, hogy ez utóbbi technológiák vonatkozásában már nem is érvényesül az fMRI-hez hasonló mértékben a mereológiai tévedés kritikája. ${ }^{56} \mathrm{~A}$ harmadik és egyben legizgalmasabb érve pedig, hogy a kritikai szemlélet figyelmen kívül hagyja a jelenlegi, hazugságok ellenőrzésére vonatkozó módszerek és az agyalapú hazugságvizsgálók költségeinek és hasznainak az összehasonlítását. ${ }^{57}$ Abban azonban a legtöbb szerző egyetért, hogy az idegtudomány jogi alkalmazhatóságának témája rendkívül felkapott, talán már túlságosan is, a tudomány jelenlegi állásához mért reális hasznosíthatóságát tekintve.

\section{A döntéshozatali folyamat kognitív pszichológiai magyarázata}

A döntéshozatal minden ember életében fontos szerepet játszik, ugyanis egy-egy igazán fontos döntés megkeserítheti vagy boldogabbá teheti az emberek életét. Tekintettel arra, hogy a bírák is emberek, ráadásul az ő döntéseik más emberek életére is kihatnak, ezért a hatékony döntéshozatali készségek és stratégiák fejlesztése kiemelten fontos szempont kell hogy legyen a bírósági szervezetben. A bírák adott ügyben történő eljárása kétségkívül döntéshozatali eljárás. A bizonyítékok megismerése, értékelése, az eljárás alá vont személy vagy a peres felek, valamint a tanúk és szakértők vallomásából egy tényállás megalkotása mind-mind olyan folyamat, amely a bíró elméjében játszódik le. A különböző döntéspszichológiai felfedezéseket a piaci élet szereplői, a vállalkozások előszeretettel alkalmazzák, így a viselkedési piacelmélet is, amely azt vizsgálja, hogy hogyan határozzák meg a racionális vállalatok szerződéseiket, árazási stratégiájukat, ha a pszichológiai torzítások a fogyasztókra is hatással vannak. ${ }^{58}$ Más tudományágak művelői is hasznosnak találják a döntéspszichológiai eredmények felhasználását, és számos területen eredményesen alkalmazták a heurisztikák és torzítások összefüggéseit, beleértve az orvosi diagnosztikát, az intelligenciamérést, a filozófiát, a pénzügyet, a statisztikát és a haditechnikai kérdéseket. ${ }^{59}$

Ha a vállalkozások hasznot húznak abból a tudásból, hogy milyen folyamatok vezetnek el egy fogyasztói döntéshez, és hogyan lehet azt befolyásolni, a bírói szervezet is hasznot húzhat az erre vonatkozó ismeretek bővítésével, a bíró saját kognitív, elmebeli sajátosságai általi befolyásolhatóságának minimumra szorításá-

${ }^{54}$ PARdo, Michael S.-PATterson, Dennis: Minds, Brains and Law: The Conceptual Foundations of Law and Neuroscience. Oxford University Press, New York, 2013.

${ }^{55}$ DANAHER: i. m., 160.

${ }^{56}$ DANAHER: i. m., 162.

${ }^{57}$ DANAHER: i. m., 181.

${ }^{58}$ SELEl Adrienn: Pszichológiai torzítások a fogyasztói döntésekben és hatásuk a vállalatok viselkedésére. Iustum Aequum Salutare VIII., 2012/3-4, 146. http://ias.jak.ppke.hu/hir/ias/20123sz/09.pdf (2020. 04. 07.).

59 KAHNEMAN, Daniel: Gyors és lassú gondolkodás. HVG, Budapest, 2012, 15. 
val. Számos tanulmány áll rendelkezésre, mely szerint a döntéshozatalt több faktor is befolyásolhatja, mint a múltbéli események, ${ }^{60}$ az egyének kora és jellemző tulajdonságai, ${ }^{61}$ a személyes jelentőségbe vetett hit ${ }^{62}$ vagy a kognitív torzítások, az utóbbiakra vonatkozó tudományos eredmények a bírói döntéshozatal vonatkozásában kitűnnek a többi közül. A következőkben a kognitív és szociálpszichológia által feltárt különböző heurisztikákat, torzításokat szeretném részletesebben bemutatni, amelyek empirikus kutatások által bizonyítottan nagyon könnyen befolyásolhatják a döntéshozatalt és ismeretükben (némi tudatos odafigyeléssel) precízebb, pontosabb döntések születhetnek.

\subsection{A heurisztikák és torzítások tana}

A heurisztikák olyan általános döntéshozatali eljárások, amelyek elengedhetetlenül szükségesek a mindennapi életben történő számos döntés meghozatala során, hiszen csökkentik a kognitív terheket, amelyre vagy az információhiány, vagy a gyors döntés igénye miatt van szükség. ${ }^{63} \mathrm{~A}$ heurisztika, szaknyelvi megfogalmazás szerint „egy olyan egyszerü eljárás, amely segít megfelelö, bár sokszor nem tökéletes választ találni nehéz kérdésekre". ${ }^{64}$ Ezekhez kapcsolódnak az egyes torzítások mint kognitív csapdák. A heurisztikák és torzítások tana erősen kötődik Kahneman és Tversky nevéhez, akik 1969-töl végeztek közös kutatómunkát, amelynek eredményeként 21 közös cikkben értekeztek az egyes kognitív sajátosságokról, a gondolatmenetet eltérítő csapdákról. Kahneman (közgazdasági Nobel-emlékdíjas pszichológus) a 2012-ben magyar nyelven is megjelent Gyors és lassú gondolkodás címü múvében az elme kétféle gondolkodási mechanizmusáról ír, amellyel összekapcsolja a heurisztikák és torzítások elméletét.

A kétféle gondolkodás elmélete szerint (dual-process thinking) - amely eredetileg Stanovich és West nevéhez kötődik - az agyban egy gyors, „automatikus rendszer” és egy lassabb, „akaratlagos rendszer” működik. Ezeket 1. rendszernek és 2. rendszernek nevezik a pszichológusok a könnyebb megértés érdekében ${ }^{65} \mathrm{Az} 1$. rendszer automatikusan és gyorsan, kevés erőfeszítéssel dolgozik, viszont kontrollját csak a 2. rendszer képezi, amely azokra az erőfeszítést igénylő mentális tevékenységekre összpontosítja a figyelmet, amelyeknél erre szükség van. ${ }^{66}$

\footnotetext{
${ }^{60}$ Jullisson, E. Ásgeir-KARLsson, Niklas-GÄrLING, Tommy: Weighing the Past and the Future in Decision Making. European Journal of Cognitive Psychology, 2005/4, 561-575. (DOI: 10.1080/09541440440000159).

${ }^{61}$ DE BRUIN, Wändi Bruine-PARKER, Andrew M.-FISCHHOFF, Baruch: Individual Differences in Adult DecisionMaking Competence. Journal of Personality and Social Psychology, 2007/5, 938-956. (DOI: 10.1037/00223514.92.5.938.).

${ }^{62}$ Acevedo, Melissa-Krueger, Joachim: Two Egocentric Sources of the Decision to Vote: The Voter's Illusion and the Belief in Personal Relevance. Political Psychology, 2004/1, 115-134. (DOI: 10.1111/j.1467-9221.2004.00359.x.).

${ }^{63}$ DIETRICH, Cindy: Decision Making: Factors that Influence Decision Making, Heuristics Used, and Decision Outcomes. Inquiries Journal, 2010/2. 1-3. http://www.inquiriesjournal.com/a?id=180 (2020. 07. 08.).

${ }^{64}$ KaHNeman: i. m., 116.

65 KAHNEMAN: i. m., 39.

${ }^{66}$ KAHNEMAN: i. m., 28.
} 
$A z$ 1. rendszer segít a könnyebb döntéseket egyszerüen, gyorsan és nagyobb igénybevétel nélkül meghozni, így az élet nagyobb kihívást jelentő, fontos feladataira engedi az elmét koncentrálni. ${ }^{67} \mathrm{~A} 2$. rendszer ezzel szemben időigényes és koncentrációt igényel, így eltereli az emberek figyelmét más cselekvéseiktől (például nehézségekbe ütközne egy kevésbé ismert nyelven kommunikálni egy indokolt ítélet megírása közben). Az 1. rendszer müködik egy elhagyatott autóúton történő vezetés során, míg a 2. rendszer az, amely egy szűk és forgalmas úton történő előzés esetén kontrollálja a reakciókat. Az 1. rendszer egyből felismeri az anyanyelven hallott szavakat, ${ }^{68}$ míg a 2. rendszer segít például kitölteni egy adóbevallást. ${ }^{69}$

Tekintettel arra, hogy az 1. rendszer automatikus, és folyamatosan benyomásokkal, impulzusokkal bombázza a 2. rendszert - amely azokat meggyőződésekké formálja ${ }^{70}$-, a gondolkodás gyors rendszere könnyen megtéveszthető. Vannak olyan gondolkodásbeli illúziók (kognitív illúziók), amelyek nem vizuális természetűek, hanem az agyunkat csapják be. Ezeket hívják torzításoknak. Az 1. rendszerből hiányzik a mérlegelés képessége, inkább csak dönt - emiatt rendkívül fogékony ezekre az illúziókra. A 2. rendszer az, amely ellenőrzi az 1. rendszert, így, ha a gyors rendszer elakadna, segítségül hívja a lassú gondolkodást. ${ }^{71}$

$A z$ 1. és a 2. rendszer közötti munkamegosztás így a leghatékonyabb, hiszen az is nagyon fárasztó lenne, ha az ember minden egyes döntését a lassabb és mérlegelő 2. rendszer hozná meg, valamint annak is káosz lenne a vége, ha mindent gyorsan döntene el az 1. rendszer a legelső impulzus szerint. Nem véletlenül mondják, hogy „számolj el háromig, mielőtt cselekednél”, hiszen a legelső gondolat intuíció alapú, ezt a tudatosságnak felül kell tudnia írni (például, hogy a bíróság méltóságát megőrző válasz szülessen egy adott tárgyalótermi szituációra, vagy hogy a tényállás elolvasása utáni bűnösségről alkotott benyomást a bizonyítékok mérlegelése felülírja). Fontos hangsúlyozni, hogy minden ember elméje más és más, mégis, az általános jellemzők mindenhol jelen vannak. Ezt erősíti meg Evans tanulmánya ${ }^{72}$ az összes olyan szakirodalom áttekintéséről, amelyek az elsődleges és másodlagos gondolkodási rendszerről szólnak.

\subsection{Az egyes torzítások}

Tekintettel arra, hogy számtalan döntéshozatalt torzító tényező ismert a szociálés kognitív pszichológia világában, elsősorban a bírói döntéshozatallal összefüggő torzító tényezőket szeretném ismertetni. Erre azért van szükség, mert még a

${ }^{67}$ RICHARDS, Diana: When Judges Have a Hunch: Intuition and Experience in Judicial Decision-Making. Archiv für Rechts-und Sozialphilosophie, 2016/2. https://papers.ssrn.com/sol3/papers.cfm?abstract_id=2009883 (2020. 04. 06.).

68 KaHNEMAN: i. m., 28.

69 KAHNEMAN: i. m., 31.

70 KAHNEMAN: i. m., 33.

71 KAHNEMAN: i. m., 33.

72 EvANS, Jonathan St. B. T.: Dual-Processing Accounts of Reasoning, Judgment, and Social Cognition. Annual Review of Psychology, 2008/59, 255-278., https://sites.ualberta.ca/ francisp/Phil488/EvansDualProcessing2008.pdf (2020. 04. 06.). 
legtehetségesebb és legelhivatottabb bírók is hibázhatnak, a közvélemény azonban azt várja el tölük, hogy hibátlanul járjanak el munkájuk során, amely elvárás természetesen irreális. Az emberi döntéseket és választásokat tanulmányozó pszichológusok felfedezték, hogy az emberek gyakran esnek áldozatául olyan kognitív illúzióknak, amelyek a döntéseikben hibákat idéznek elő. Annak ellenére, hogy a bírák jól képzett, tapasztalt és erősen motivált döntéshozók, fogékonyak maradhatnak a kognitív illúziókra. Ez azonban teljesen természetes, amely minden emberre jellemzö, ezt az emberi elme olyan sajátosságai okozzák, amelyek a hétköznapi döntések meghozatalához szükségesek.

Empirikus kutatási eredményekkel igazolható és leggyakoribb kognitív illúziónak tekinthető a lehorgonyzás, a kerethatás, az utólagos bölcsesség, a reprezentativitási heurisztika, és az egocentrikus torzítás, amelyek mind befolyásolhatják a döntéshozatalt. Ezeket vizsgálta 167 szövetségi bíró részvételével Guthrie, Rachlinski és Wistrich empirikus kutatásaik során, amelyek eredményét 2001-ben publikálták a Cornell Law Review folyóiratban. ${ }^{73}$ Empirikus kísérleteikbe a bírák mellett esküdteket is bevontak, így érdekessége a kísérletnek, hogy a bírák az 5 kognitív illúzióból 2-vel szemben ellenálóbbak voltak (reprezentativitási heurisztika, kerethatás), mint az esküdtek, akiknek mind az 5 torzítás jelentősen befolyásolta a döntéshozatalát. Mindenesetre a kutatások azt bizonyítják, hogy „, a bírák is emberek”, ${ }^{74}$ még ha néhány esetben kevésbé látványosan is, de hatással vannak döntéseikre a kognitív illúziók, mint minden más ember esetében.$^{75} \mathrm{E}$ megállapítás megegyezik azzal, amit már az amerikai jogi realizmus képviselői is állítottak, hogy a bíró egyéni vonásai, hajlamai, beállítottsága és szokásai, a lélektani motívumok is befolyásolják a bírói döntéshozatalt. ${ }^{76}$ Azonban ezek a kísérletek az emberi elme müködésére helyezik a hangsúlyt, és a kognitív döntéspszichológia módszerével elemzik a megállapítás helyességét.

\subsubsection{Lehorgonyzás}

Amikor az emberek számszerü becsléseket végeznek (például hogy milyen a piaci ára egy lakásnak), gyakran támaszkodnak a számukra elérhető kezdőértékekre (például listaár). Ez a kezdőérték az, aminél lehorgonyoznak, és ahonnan elvégzik számításaikat, míg eljutnak a végső, becsült értékig. ${ }^{77}$ Számos szituációban előfordulhat, hogy észszerủ a lehorgonyzás, ugyanis ezek a kezdőértékek fontos információt hordozhatnak magukban valamilyen termék valós értékéről (annak ellenére,

${ }^{73}$ GUthrie, Chris-RAChlinSKI, Jeffrey J.-WISTRICH, Andrew J.: Inside the Judicial Mind. Cornell Law Faculty Publications, 2001, 778-830. https://scholarship.law.cornell.edu/cgi/viewcontent.cgi?article=1734\&context=facpub (2020. 03. 30.).

74 Guthrie, Chris-Rachlinski, Jeffrey J.-Wistrich, Andrew J.: Blinking on the Bench: How Judges Decide Cases. Cornell Law Faculty Publications, 2007/2. 13. https://scholarship.law.cornell.edu/facpub/917 (2020. 05. 29.).

75 GUTHRIE-RACHLINSKI-WISTRICH (2001): i. m., 779.

${ }^{76}$ FEDOR Anett: Gondolatok Jerome Frank „Bíráskodás az elme ítélőszéke előtt” című válogatott írásairól. Büntetőjogi Szemle, 2014/2, 30. https://ujbtk.hu/wp-content/uploads/2014/06/bjsz_201402_fedor_anett.pdf (2020. 05. 29.).

77 GUTHRIE-RACHLINSKI-WISTRICH (2001): i. m., 787. 
hogy az emberek túlságosan is támaszkodnak a kezdőértékre). A problémát az jelentheti, amikor a kiinduló érték nem hordoz magában releváns információt a termék valós értékéről, és ez erősen befolyásolja a döntéshozatalt. ${ }^{78} A$ tanulmányok azt is kimutatták, hogy a számok még akkor is rögzítési pontként szolgálhatnak, ha a döntéshozók teljesen tisztában vannak az irrelevanciájukkal. ${ }^{79}$

A kiindulási értékek egyfajta viszonyítási alapot adnak, amelyek hatással vannak arra, hogy milyen irányba haladnak a számok becslésére irányuló gondolatok. Annak feltételezésére ösztönzik az embereket, hogy komoly esélye van a valós érték és a kiindulási érték egymáshoz közeledésének, így lelki szemeik előtt azt látják, hogy ez a kezdő érték helyes is lehet. Még ha az emberek fel is ismerik, hogy a kiinduló érték nem hordoz magában hasznos információt, érvényességének mentális tesztelése miatt az emberek ehhez az értékhez viszonyítva határozzák meg a végső értéket, amely a kiinduló értékhez képest lesz alacsonyabb vagy magasabb. ${ }^{80}$ Így például, ha a hallgatókat arról tájékoztatja az előadó, hogy ma már magasabb összegre becsülik egy átlagos tankönyv árát 15000 forintnál, akkor ez lesz a kiindulási pont, ami radikálisan magas, így arra ösztönözheti a diákokat, hogy elgondolkodjanak ennek az összegnek a lehetőségén. Következésképp ennél az összegnél fognak (feltehetöleg) alacsonyabb összeget megállapítani. Ez persze magasabb lesz, mintha csak annyit kérdezett volna tölük a tanár, hogy körülbelül mennyibe kerül egy tankönyv.

Hogyan merülhet fel a bírósági eljárásban a lehorgonyzás torzítása? Kutatások bizonyították, hogy a hatás érvényesül a közvetítői eljárás során a felperes által elfogadhatónak tekintett sérelemdíj összege ${ }^{81}$ ezen túlmenően a felperes által a keresetlevélben követelt összeg tekintetében is, de el lehet képzelni a hazai büntetőeljárásjogban a polgári jogi igény szándékosan magas összegü bejelentése esetén, ugyanígy feltételes ügyészi felfüggesztés esetén megkötendő egyezség vonatkozásában. Ezek arra késztethetik a bírót, hogy egy magasabb összegről kezdjen el gondolkodni, mint amennyit valójában meg kellene ítélni.

Guthrie, Rachlinski és Wistrich empirikus kutatásuk során a bírák egy csoportjának kiindulási értékkel bíró jogesetet adtak, míg a kontrollcsoportnak olyan jogesetet, amelyben nem szerepelt ilyen érték. A kiindulási érték (egy alacsonyabb, 75000 dolláros összeg) meghatározta a gondolkodás irányát, így jelentős hatással volt a megítélt kártérítésekre. A kontrollcsoportban részt vett 66 bíró átlagosan 1249000 dollár kártérítést adott volna, míg a horgony-hatással bíró jogesetet megoldók átlagosan 882000 dollárt. ${ }^{82}$ A különbség tehát statisztikailag szignifikáns volt.

Mindez azt jelenti, hogy a bírák megvizsgálták annak a lehetőségét, hogy akár a szokásosnál alacsonyabb összegü, 75000 dollár is lehetne a megítélendő kártérítési

78 GUTHRIE-RACHLINSKI-WISTRICH (2001): i. m., 788.

79 TeIchman, Doron-ZamiR, Eyal: Judicial Decisionmaking: A Behavioral Perspective. In: Zamir, Eyal-Teichman, Doron (szerk.): The Oxford Handbook of Behavioral Economics and the Law. Oxford University Press, Oxford, 2014, 15.

80 TEICHMAN-ZAMIR: i. m., 788.

${ }^{81}$ Korobkin, Russell-Guthrie, Chris: Opening Offers and Out-of-Court Settlement: A Little Moderation May Not Go a Long Way. The Ohio State Journal on Dispute Resolution, 1994/1, 1-22. https://pdfs.semanticscholar.org/df2a/2acf29f47c562b5aa8548a33fc1a01243285.pdf (2020. 04. 06.).

82 GUTHRIE-RACHLINSKI-WISTRICH (2001): i. m., 791. 
összeg. Feltehetőleg ilyenkor olyan korábbi jogesetek játszódtak le az elméjükben, amelyeknél alacsony kártérítési összeget kellett megítélniük, így agyuk kitöltötte az általuk nem ismert részleteket az üggyel kapcsolatban, és úgy gondolták, valóban alacsony összeget kell megítélni. ${ }^{83} \mathrm{~A}$ tanulmányban felvetik, hogy a bírák akár releváns információkat is társíthattak az alacsony összeg mellé, így például elgondolkodhattak azon, hogy ha a felperes csak ennyit kér, akkor valószínüleg a saját álláspontja szerint ennyit érdemel. Chapman és Bornstein tanulmánya azonban ezt cáfolja, szerintük a bírák tudatában vannak annak, hogy ez nem egyenértékü a felperes által elszenvedett kárral, gondolkodási mechanizmusukra azonban még így is kihatással van a torzítás. ${ }^{84}$ Ugyanakkor bizonyítható, hogy a vagyoni kártérítés öszszege komolyabb hatással van az esküdtekre, mint a bírákra. Ez azt mutatja, hogy a laikusok sokkal inkább a hatása alá kerülnek a felperes vagyoni veszteségének, amikor a sérelemdijat vagy a polgári jogi igényt határozzák meg. ${ }^{85}$

Egy jogtudósból, szociálpszichológusból és közgazdászból álló csapat szintén folytatott empirikus kutatásokat a lehorgonyzás torzításának vizsgálatára. Tanulmányukban arról írnak, hogy a számtalan elemző munka mellett az ő kutatásuk az első, amely valós perek lefolyását vizsgálta magas ügyszámmal. ${ }^{86}$ Nemcsak ők, de Teichman és Zamir is rámutatnak, ${ }^{87}$ hogy a bírósági szervezet már nem hagyhatja sokáig figyelmen kívül ezt a jelenséget, sőt, azt a jogalkotásnak is számításba kell vennie, amikor megalkotja az eljárásjogi rendelkezéseket a jogalkalmazók számára. Yun-Chien, Kong-Pin és Chang-Chin empirikusan nyert adatokkal támasztja alá, hogy a felperes által megjelölt, a perben elbírálandó összegek magasabbak, ha az alperes nem nyújt be viszontkeresetet, mint amennyiben igen. Azt is megállapították, hogy a torzítás nincs jelen ilyen jelentős mértékben a tapasztaltabb bírák esetében, az inkább a kezdő bírákat érinti, így tapasztalattal kiküszöbölhető. Az elemzésben azt is megállapítják, hogy ha a bírónak indokolnia kell döntését, az csökkenti a hatás érvényesülését. ${ }^{88}$

\subsubsection{Kerethatás}

Amikor az emberek kockázatos döntésekkel találják szembe magukat - mint például, hogy egyezséget kössenek vagy tárgyaljanak - aszerint kategorizálják a döntési lehetőségeiket, hogy azok hasznokkal járnának-e, vagy költségekkel. Ekkor a legegyértelmübb, fennálló állapothoz, mint hozzáigazítási ponthoz viszonyítanak,

${ }^{83}$ GUTHRIE-RACHLINSKI-WISTRICH (2001): i. m., 792.

${ }^{84}$ Chapman, Gretchen B.-BornsteIn, Brian H.: The More You Ask for the More You Get: Anchoring in Personal Injury Verdicts. Applied Cognitive Psychology, 1996/10, 519-540. (DOI: 10.1002/(SICl)1099-0720 (199612)10:6<519::AID-ACP417>3.0.CO;2-5).

85 Teichman-ZamiR: i. m., 16.

${ }^{86}$ YUn-CHIEN, Chang-Kong-PIN, Chen-CHANG-CHIN, Lin: Anchoring Effect in Real Litigation: An Empirical Study. University of Chicago Coase - Sandor Institute for Law \& Economics Research Paper No. 744. (2016), 38. https://papers.ssrn.com/sol3/papers.cfm?abstract_id=2726903 (2020. 04. 07.).

87 TeICHMAN-ZAMiR: i. m., 30.

${ }^{88}$ YUNG-CHIEN-KONG-PIN-CHANG-CHIN: i. m., 39. 
ezt nevezzük „status quo”-nak. ${ }^{89} \mathrm{~A}$ döntési lehetőségek kategorizálása vagy „keretezése" befolyásolja az opciók értékelését és a kockázatvállalási hajlandóságot. Amikor hasznokkal járó döntési lehetőségekkel néznek szembe, az emberek nem szeretnek kockáztatni, amikor viszont költségekkel járó lehetőségeik vannak, sokkal hajlandóbbak kockázatot vállalni. Így például, az emberek inkább választanak 10000 forint fix hasznot, minthogy $50 \%$ eséllyel 20000 forintra tegyenek szert, és inkább veszítenek el 50\%-os valószínűséggel 20000 forintot, minthogy biztosan elveszítsenek 10000 forintot. Ez azért érdekes, mert a racionális választás szempontjából az emberek kockázatvállalásának az alapja az ő jólétük kellene, hogy legyen, amelyhez képest mérlegelik a tétet. A gyakorlatban úgy tűnik azonban, hogy mégsem ez a helyzet, az emberek nem végeznek normatív módon helyes számításokat. Éppen ellenkezőleg, az emberek választása azon alapszik a gyakorlatban, hogy megtartsák vagy fejlesszék a status quót. Ez pedig a hasznok esetén a kockázat elkerülését, míg költségek esetén a kockázat vállalását jelenti. ${ }^{90}$

A kerethatásnak mély nyoma kell hogy legyen a polgári eljáráson, ugyanis a perindítás számtalan természetes kerethatást hoz magával. A legtöbb ügyben a felperesek döntik el, hogy közvetítői eljárás keretében megállapodnak-e az alperessel vagy inkább kockáztatnak és reménykednek abban, hogy a bíró magasabb összeget ítél meg részükre. Az alperesek ezzel ellentétben eldönthetik, hogy fizetnek-e a közvetítői eljárás keretében, vagy inkább a bíróra bízzák a döntést, hátha esetleg kevesebbet kell majd fizetni, mint amennyit a felperes kért a közvetítés során. A felperesek számukra haszonnal járó lehetőségek közül, míg az alperesek számukra veszteséggel járó lehetőségek közül választhatnak. Így a kutatások szerint a felperesek hajlandóbbak az egyezségkötésre és elkerülnék a kockázatot, míg az alperesek szívesebben kockáztatnak, hátha elkerülik a nagyobb veszteséget. ${ }^{91}$ Gilliland és Dunn is két, több mint 500 résztvevővel folytatott kísérlete eredményeként is azt állapította meg, hogy a peren kívüli vitarendezés sikerét két tényező határozza meg: egyrészt az a keret vagy referenciapont, amelyből indulnak az ajánlatok, és a valószínüsíthető pozitív vagy negatív eredménye az esetleges tárgyalásnak ${ }^{92} \mathrm{Ez}$ az első tanulmány, amely kontrollcsoportot alkalmazva a keret hatásától függetlenül is vizsgálta a résztvevők döntéseit, így e második kutatás segít tisztázni a peres felek korábbi, kerethatás nélküli döntéshozatalának eredményeit. A kísérletek eredménye alátámasztotta, hogy a felperesek és az alperesek egyaránt hajlamosak a kognitív illúzióra, azonban a status quo fenntartására irányuló törekvés nem volt annyira egyértelmü, észrevehető volt bizonyos eltolódás abban a kérdésben, hogy mikor melyik

${ }^{89}$ GUTHRIE-RACHLINSKI-WISTRICH (2001): i. m., 794.

${ }^{90}$ GUTHRIE-RACHLINSKI-WISTRICH (2001): i. m., 795.

${ }^{91}$ A bírósági ügyeket tekintve álláspontom szerint nem elhanyagolható a peres felek közti érzelmi viszonyulás sem, mert lehetséges, hogy kognitív szinten a per elkerülése lenne az emberek első gondolata, de ezt felülírhatják olyan érzelmi viszonyulások, mint a bosszúvágy vagy az ego megnyilvánulása, a másik peres fél feletti győzni akarás.

${ }_{92}$ GILliLAND, Victoria-DunN, John C.: Decision Making in Civil Disputes: The Effects of Legal Role, Frame, and Perceived Chance of Winning. Judgment and Decision Making, 2008/7, 512-527. http://journal.sjdm.org/8610/ jdm8610.pdf (2020. 04. 06.). 
fél szeretné a veszteséget elkerülni és a hasznot maximalizálni. ${ }^{93}$ Ez arra utalhat, hogy a kognitív gondolkodási folyamat nem mechanikus, elöfordul, hogy a személyiség és az egyéni preferenciák felülírják az elme által sugallt döntést (így vált át az agy 1 . automatikus rendszere a 2 . rendszerre).

Természetesen a bírák is aktív szerepet játszanak az egyezségkötés során, ők vizsgálják felül a megállapodásokat. Felmerül a kérdés, hogy vajon a kerethatás miatt másképp ítélik-e meg a felperesek és az alperesek döntését? Ahhoz, hogy a kerethatás bírói döntést befolyásoló hatását megvizsgálják, Guthrie, Rachlinski és Wistrich a kutatásban részt vevő 167 bírónak egy fiktív tényállást mutatott be. A feladat a következő volt:

\begin{abstract}
Képzelje el, hogy ön tárgyalja az ügyet, amelyben a felperes 200000 dollárra perelte az alperest egy szerzői jogi ügyben. Mind a felperes, mind az alperes középvállalkozások, amelyek éves bevétele 2,5 millió dollár. Mindkét felet képzett jogász képviseli, aki azonban még nem tárgyalt hasonló ügyet korábban. Egyszerü ügynek tünik, de felvet néhány érdekesebb kérdést is. Nincs ugyanis vita a pénzügyi oldalról, csak arról, hogy az alperes megsértette-e a felperes szerzői jogát. Úgy gondolja, hogy $50 \%$ esély van arra, hogy a felperes megtéríti a 200000 dollárt, és $50 \%$ esély, hogy semmit sem fog fizetni az alperesnek. Számításai szerint amennyiben a feleknek nem sikerül megegyezniük, mindkét fél kb. 50000 dollárt fog költeni perköltség címén. Feltehetőleg jelen esetben egyik félnek sem kell majd az eljárás végén a másik fél perköltségét megtéríteni. ${ }^{94}$
\end{abstract}

A jogeset így folytatódott: „az ügyben kitüzte a tárgyalás napját, és elötte egy egyezségkötésre irányuló meghallgatást". ${ }^{95}$ A bírák fele a felperes nézőpontjából láthatta a jogesetet, melyben a lehetséges hasznokról tájékoztatták a következők szerint: „Önnek tudtára adták, hogy az alperes szándékában áll 60000 dollárt fizetni a felperesnek, ha megegyeznek. Ön úgy gondolja, hogy a felperesnek ebbe bele kellene egyeznie?"'96 Ezen túlmenően a bíráknak azt is tudtára adták, hogy a felperes választása a biztos 60000 dollár haszon vagy a tárgyalás során a lehetősége: $50 \%$ esélye van arra, hogy megkapja a 200000 dollárt, így az is lehet, hogy nem kap semmit, valamint ott az 50000 dollár kiadás a perköltségre, ez így átlagolva 50000 dollár haszonnak tekinthetö.

A bírák másik fele az alperes perspektívájából szemlélte az ügyet: „Önnek tudtára adták, hogy a felperes szándékában áll elfogadni 140000 dollárt egyezségkötés esetén. Ön úgy gondolja, hogy az alperesnek ki kellene fizetnie ennyi pénzt, hogy egyezséget kössenek?" Ezen túlmenően a bírákat tájékoztatták, hogy az alperes választási lehetősége a biztos 140000 dollár kiadás, vagy pedig a tárgyalás eredményeként $50 \%$ eséllyel 200000 dollár vagy 0 dollár kiadás és az 50000 dollár perköltség, amely átlagolva 150000 dollár kiadást jelent.

Minden bírónak csak egy igennel vagy egy nemmel kellett válaszolnia.

\footnotetext{
${ }^{93}$ Gilliland-DunN: i. m., 524.

94 GUTHRIE-RACHLINSKI-WISTRICH (2001): i. m., 796.

95 GUTHRIE-RACHLINSKI-WISTRICH (2001): i. m., 796.

96 GUTHRIE-RACHLINSKI-WISTRICH (2001): i. m., 797.
} 
Az eredmények a keretnek megfelelően változtak. A felperes szemszögéböl figyeló bírák 39,8\%-a gondolta úgy, hogy a felperesnek el kellene fogadni a 60000 dolláros egyezségi ajánlatot, de csak 25\%-uk mérlegelte az ügyet az alperes szemszögéböl úgy, hogy ki kellene fizetnie a 140000 dollárt az egyezségkötés során. Lényeges eltérés volt a két csoport döntése között, így a peres felekhez hasonlóan a bírákat is befolyásolta a tényállás keretbe foglalásának módja. ${ }^{97}$

Érdekes, hogy a kerethatásokat figyelembe véve a bírák többsége $(67,5 \%$, azaz 110 a 163 föböl) úgy gondolta, hogy a feleknek nem szabadna egyezséget kötnie, annak ellenére, hogy az egyezségi ajánlat mind a felperes, mind az alperes számára messze volt az elvárt tárgyalási eredménytől. Ez azt jelenti, hogy a bírák még inkább kockázatvállalók, azaz "tárgyalást vállalók”, mint mások. ${ }^{98}$ Természetesen ehhez más pszichológiai magyarázatok is hozzájárulnak, ez nem csupán a kognitív illúziók hatása, ennek tudatos okai is vannak. ${ }^{99}$

\subsubsection{Utólagos bölcsesség}

Az utólagos bölcsesség azt a jelenséget írja körül, hogy az emberek túlzottan magabiztosak azon képességüket illetően, hogy megjósolhatták-e az eseményeket azok bekövetkezte elött, és másokról is azt gondolják, hogy reális esélyük lett volna erre. ${ }^{100} \mathrm{~A}$ pszichológusok éppen ezért nevezték el a jelenséget utólagos bölcsességnek (esetenként utólagos torzításnak nevezik), ami a mindenki által jól ismert kijelentésre utal: „Én megmondtam.”

A jelenség előfordulásának az az oka, hogy egy eredmény bekövetkezése megerősíti az embereket a világról alkotott elképzeléseikben. ${ }^{101} \mathrm{Az}$ emberek ezt követöen már másképp ítélik meg az esemény bekövetkeztét és figyelmen kívül hagyják azt a megelőző állapotot, amelyben még nem játszott szerepet az eredmény okozta megerősítés, ez az előzetes és utólagos állapot egyenlőtlenségére utal. ${ }^{102}$ Kísérleti úton általában úgy szokták vizsgálni, hogy a résztvevők elé tárják egy esemény több lehetséges kimenetelét is, azok közül egy biztos eredményt kiemelve, majd megkérdezik, hogy melyikre tippelnek. Ezután minden eredmény valószínüségét értékelniük kell. Annak ellenére, hogy a résztvevőknek elmondják, hogy mindegyik eredmény ugyanolyan mértékben lehet igaz, mint hamis, sokkal nagyobb valószínúséget szavaznak annak az eredménynek, melyre a kísérletvezetők előrejelzést tettek. ${ }^{103}$

97 GUTHRIE-RACHLINSKI-WISTRICH (2001): i. m., 797.

98 GUTHRIE-RACHLINSKI-WISTRICH (2001): i. m., 798.

99 Így például bizonyosan hozzájárul ehhez a tendenciához az, hogy ők ismerik a tárgyalótermet, így nem félnek tőle (ami az ügyfelek esetében inkább előfordulhat), valamint hogy nekik ez a munkahelyük, mások valószínủleg inkább tehernek élik meg a tárgyaláson való részvételt.

100 GUTHRIE-RACHLINSKI-WISTRICH (2001): i. m., 799.

101 HAWKINS, Scott A.-HASTIE, Reid: Hindsight: Biased Judgments of Past Events After the Outcomes are Known. Psychological Bulletin, 1990/3, 311-327., https://www.academia.edu/11926617/Hindsight_Biased_judgments_of_past_events_after_the_outcomes_are_known (2020.04. 05.).

102 EYAL, Peer-Eyal, Gamliel: Heuristics and biases in judicial decisions. Court Review, 2013/49, 115. http://aja. ncsc.dni.us/publications/courtrv/cr49-2/CR49-2Peer.pdf (2020. 04. 05.).

${ }^{103}$ FISCHHOFF, Baruch-BEYTH, Ruth: I Knew It Would Happen: Remembered Probabilities of Once-Future Things. Organizational Behavior and Human Performance, 1975/1, 13. https://www.researchgate.net/publication/ 223213727_I_Knew_It_Would_Happen_Remembered_Probabilities_of_Once-Future_Things (2020. 04. 05.). 
Ugyan a hétköznapokban is gyakran elöfordul olyan helyzet, ami azt várja az emberektől, hogy értékeljék a múltbéli események bekövetkezésének lehetőségét, de ez a feladat a jogi döntéshozatalt is áthatja, amelyet számos tanulmányban teszteltek már. Az egyik ilyen értekezésben Kamin és Rachlinski összehasonlította az emberek azon (esemény bekövetkezte elötti) döntését, hogy szükség van-e óvintézkedésre egy áradás ellen, azzal az utólagos döntéssel, hogy az óvintézkedés elmulasztása tekintetében felelösség terheli-e a döntéshozót. ${ }^{104} A$ résztvevők egy körével közölték, ha úgy gondolják, hogy az áradás valószínűsége minden évben nagyobb, mint $10 \%$, akkor javasoljanak óvintézkedést. Ezt követően az előbbi résztvevők döntését értékelő tesztalanyok részére azt mondták, hogy az áradás megtörtént, de az óvintézkedés elmaradt, és emiatt 1 millió dollár összegủ kár keletkezett. Feladatuk az volt, hogy ha úgy gondolják, hogy az áradás valószínűsége az áradást megelőzően 10\% feletti kellett, hogy legyen, akkor állapítsák meg az óvintézkedés elmulasztása miatt az alperes felelösségét. ${ }^{105}$

Habár a résztvevők mindkét csoportja ugyanannyi információval rendelkezett az áradás előfordulásának valószínűségéről, különböző konklúzióra jutottak az alperes helyes eljárását illetően. Az első csapatban részt vevők 24\%-a mondta, hogy az áradás valószínüsége indokolja az óvintézkedés megtételét, míg a döntést értékelők 57\%-a állította, hogy az áradás megjósolható lett volna, és az óvintézkedés elmulasztása hanyagságból történt. ${ }^{106} \mathrm{Az}$ utólagos bölcsesség tehát abban áll, hogy az esemény előtt az emberek többsége számára még az óvintézkedéstől való eltekintés tünt indokoltnak, míg az esemény bekövetkezése után ugyanez a legtöbb résztvevőnek már értelmetlen döntésnek tünt. ${ }^{107}$

Guthrie, Rachlinski és Wistrich a már említett, 167 bíró részvételével történt empirikus kísérletében minden bírónak egy fiktív tényállást adott elö, akiknek a másodfokú bíróság döntésének ismeretében kellett döntenie, mintha csak az alapügyet bírálná el. Az eset a következő volt.

1991-ben egy állami börtönör pert indított az Igazságügyi Minisztérium elnöke ellen, ugyanis állítása szerint a Minisztérium megsértette az egészségügyi ellátáshoz füződő jogát és az azt biztosító cikkelyt. A kerületi bíróság elutasította a keresetét arra hivatkozással, hogy az Igazságügyi Minisztérium nem sértette meg az említett cikkelyt, továbbá a felperesnek tudnia kellett volna, hogy keresete nem elfogadható, ugyanis számos hasonló pert indított évekkel korábban, melyek eredményeként szintén elutasították keresetét. A bíróság meg is büntette a felperest a rosszhiszemü pervitel miatt és elöírta, hogy ha legközelebb pert szeretne indítani, csak föbírói engedéllyel teheti meg. A felperes fellebbezést nyújtott be a döntéssel szemben. ${ }^{108}$

A bírák részére véletlenszerủen osztották ki a jogeseteket, amelyekhez 3 különféle másodfokú döntés is adott volt:

\footnotetext{
${ }^{104}$ Kamin, Kim A.-RACHLINSKI, Jeffrey J.: Ex Post $\neq$ Ex Ante: Determining Liability in Hindsight. Cornell Law Faculty Publications, 1995/1, 93. https://scholarship.law.cornell.edu/facpub/646 (2020. 04. 05.).

105 KAMIN-RACHLINSKI: i. m., 97.

106 KAMIN-RACHLINSKI: i. m., 98.

107 GUTHRIE-RACHLINSKI-WISTRICH (2001): i. m., 800.

108 GUTHRIE-RACHLINSKI-WISTRICH (2001): i. m., 801.
} 
- „új eljárásra utasítás” esetén a másodfokú bíróság új eljárásra utasította az elsőfokú bíróságot, hogy enyhébb szankciót alkalmazzon a felperessel szemben.

- „helybenhagyás” esetén a másodfok egyetértett az elsőfokú bíróság döntésével.

- „hatályon kívül helyezés” esetén a másodfokú bíróság szerint az elsőfokú bíróság megsértette az eljárásjogot, amikor szankciót alkalmazott a felperessel szemben. ${ }^{109}$

Minden bírónak ugyanaz volt a feladata: hogy jósolják meg a három döntés melyikét hozta a másodfok, mi volt a legvalószínúbb lehetőség (amennyiben csak ez a három variáció lehetséges). Az alanyok ezután meghallgatták a három lehetséges döntést egymás után. A kísérletvezetők azt feltételezték, hogy ha nem befolyásolja a döntés közlése a helyes döntés kiválasztását, akkor az eredmény tudatában nem szabadna eltérő döntést hozni, mint anélkül. ${ }^{110}$

Azonban az eredmények szerint az, hogy a bírák tudatában voltak a fellebbezés eredményének, jelentősen kihatott arra, hogy hogyan ítélték meg az alapügyet. Azok a bírák, akiket tájékoztattak a lehetséges kimenetelről, sokkal inkább értettek egyet a másodfokú döntés helyességével. Abban az esetben, amikor a jogeset szerint a másodfok helybenhagyta az elsőfokú ítéletet, a bírák 81,5\%-a azt állította, hogy ő is helybenhagyta volna. Ezzel ellentétben, akiknek azt mondták, hogy a másodfok megsemmisítette a döntést, csak 27,8\%-uk hagyta volna helyben a döntést, akiknek pedig új eljárásra utasításról számoltak be, azoknak 40,4\%-a. ${ }^{111}$

A kísérlet rávilágít az utólagos bölcsesség lényegére. Amikor a bíráktól megkérdezték, hogy milyen döntést hozhatott a másodfok, a döntés közlése teljesen irreleváns volt abból a szempontból, hogy mi az ő véleményük, amely kialakításához elég lett volna a tényállás értékelése. Mégis megváltoztatta a véleményüket a másodfokú döntés közlése, amelynek fényében magáról a tényállásról és annak elbírálásáról is változott a véleményük. ${ }^{112}$

Összességében megállapítható, hogy az utólagos bölcsesség valamilyen mértékben hatással van a döntéshozó figyelmére, könnyen el tudja azt terelni. Tekintettel arra, hogy a bíráknak legtöbbször éppen az a feladatuk, hogy az esemény bekövetkezte után értékeljék az ahhoz vezető folyamatot, így az utólagos bölcsesség csapdája számos veszélyt rejt számukra. A felelősségalapítás szabályai mögött a jelenség hatással van a jogi képviselet ellátásával okozott kártérítési keresetek elbírálására is (hiszen egy védöügyvéd által ellátott kötelezettség könnyen tekinthetö elmulasztottnak, ha az ügyfelét utóbb elítélték). Ugyanígy a bíróság elleni kártérítési perekre is igaz ez, hiszen egy indítvány vagy állítás kevésbé tünik igaznak, miután a bíróság már elutasította azt. ${ }^{113}$ De ide sorolhatjuk a vezető tisztségviselők kártérítési felelősségének megítélését is, hiszen a gazdasági társaság teljesítőképességét esetleg rosszul értékelhetik a fizetésképtelenséggel fenyegető gazdasági esemény bekövetkezte előtt (ha az események mégsem az elképzeléseiknek megfelelően

\footnotetext{
109 GUTHRIE-RACHLINSKI-WISTRICH (2001): i. m., 802.

110 GUTHRIE-RACHLINSKI-WISTRICH (2001): i. m., 802.

111 GUTHRIE-RACHLINSKI-WISTRICH (2001): i. m., 802-803.

112 GUTHRIE-RACHLINSKI-WISTRICH (2001): i. m., 803-804.

113 Guthrie-RACHLINSKI-WISTRICH (2001): i. m., 800.
} 
zajlanak, utóbb már bủncselekménynek tủnhet a teljesítőképességre vonatkozó túlzott önbizalom). Bizonyosan számos olyan lehetőség van még a jogban, mely esetben az utólagos bölcsesség torzítja az események megítélésének pontosságát. Ha a bírák nem figyelnek oda erre a torzításra, akkor könnyen nagyon nehéz helyzetbe kerülhet az alperes vagy a vádlott, hiszen őt az esemény bekövetkezte előtti mérlegelésben nem érhette az a kivételes lehetőség, hogy biztos legyen a kimenetelben (így például kockázatosabbnak tủnik egy orvosi beavatkozás, ha tudjuk, hogy utóbb a beteg elhunyt). Ezt a bíráknak mindig érdemes szem elött tartani, ha valamely tevékenység vagy mulasztás miatt az eljárás alá vont személy felelősségéről kell dönteni.

\subsubsection{Irreleváns információ}

Némileg kapcsolódik az előző torzításhoz az irreleváns információk hatása a gondolkodásra. Úgy tủnik, hogy az emberi agy nem arra lett kitalálva, hogy figyelmen kívül hagyjon valamilyen információt, ha már egyszer tudomása van róla. Habár a jogtudósok még vitáznak azon, hogy rendelkeznek-e a bírák egyfajta különleges képességgel az irreleváns információk kizárására, vagy sem, ${ }^{114}$ valószínűleg „a természet nem úgy alkotta meg a bírói elmét, hogy abban 'gondolatzáró' rekeszek is legyenek a jogelmélet elvárásainak való megfelelés érdekében, így a meggyőző bizonyiték a birói elmén is nyomot kell, hogy hagyjon". ${ }^{115}$

Irreleváns információként jöhet szóba a kizárt bizonyítékok köre, amelyeket nem szabadna figyelembe venni a büntetőjogi fökérdésben történő döntéshozatal során. ${ }^{116}$ Így például az eljárás egy korábbi szakaszában tett vallomás, amit erőszak hatására tettek, de abban a vádlott bevallotta a bűnösségét. llyen lehet még például a nyomozó hatóság által szabálytalanul lefolytatott eljárásból származó bizonyíték, esetleg egy jogosulatlanul végzett titkos információgyűjtés alkalmával lehallgatott beismerő vallomás. Az Amerikai Egyesült Államokban végzett kutatások eredménye szerint, főként az esküdtekre jellemző, hogy nagyon nehezen hagyják figyelmen kívül ezeket az információkat. ${ }^{117}$

Landsman és Rakos egy bírák és esküdtek részvételével végzett kísérletröl számolnak be tanulmányukban, ${ }^{118}$ akiket arra kértek, hogy döntsenek egy hipotetikus termékfelelősségi ügyben. Az egyik csoportban a résztvevőket olyan tényekröl tájékoztatták, amelyeket nem lehetne az eljárásban felhasználni, míg a kísérlet másik

114 RACHLINKSKI, Jeffrey J.-WISTRICH, Andrew J.: Judging the Judiciary by the Numbers: Empirical Research on Judges. Annual Review of Law and Social Science, 2017/13, 25. https://scholarship.law.cornell.edu/cgi/ viewcontent.cgi?article=2668\&context=facpub (2020. 04. 06.).

115 MAguiRE, John M.-EpStein, Charles S.: Rules of Evidence in Preliminary Controversies as to Admissibility. Yale Law Journal, 1927/8, 1116-1117. https://digitalcommons.law.yale.edu/cgi/viewcontent.cgi?article=3234\&context=ylj (2020. 04. 06.).

116 SUE, Stanley-SMith, Ronald E.-CALDWELL, C.: Effects of Inadmissible Evidence on the Decisions of Simulated Jurors: A Moral Dilemma. Journal of Applied Social Psychology, 1973/4, 345-353. (DOI: 10.1111/j.15591816.1973.tb02401.x.).

117 TEICHMAN-ZAMIR: i. m., 9.

118 LANDSMAN, Stephan-RAKos, Richard F.: A Preliminary Inquiry into the Effect of Potentially Biasing Information on Judges and Jurors in Civil Litigation. Behavioral Sciences and the Law, 1994/12, 113-126. (DOI: 10.1002/ bsl.2370120203). 
csoportját arra is kioktatták, hogy az információk elfogadhatatlanok, és azokat figyelmen kívül kell hagyni; a kontrollcsoport jogesete pedig egyáltalán nem tartalmazott elfogadhatatlan információt.119 A kontrollcsoporthoz képest az elfogadhatatlan információk negatív hatással voltak mind a bíró, mind pedig az esküdtek döntéseire. Érdekes, hogy a bizonyítékok kizártságára vonatkozó figyelmeztetésnek nem volt hatása a bírákra és az esküdtekre sem, ami mintha arra utalna, hogy még a jogi kioktatás sincs olyan nagy hatással a kognitív illúziókra. ${ }^{120}$

Wistrich, Guthrie és Rachlinski az előző tanulmányban felvázolthoz hasonló kísérletek sorozatát folytatta le. ${ }^{121}$ Előfordult, hogy az irreleváns információ a felperes korábbi elítéléseit tartalmazó dokumentum volt, de olyan is, hogy az ügyvéd-ügyfél beszélgetés lehallgatásának anyaga, vagy éppen egy nemi erkölcs elleni bűncselekmény gyanúsítottjának nemi életére vonatkozó részletek. ${ }^{122} \mathrm{~A}$ kísérlet eredményeként megállapították, hogy a bírák - néhány kivétellel - nem tudják teljes mértékben figyelmen kívül hagyni ezeket az információkat. Csak azt követően tudták ténylegesen kizárni elméjükből ezeket az információkat, ha szembesítették őket az eredményekkel.

Ezek alapján nagyon sokban a bírák sem különböznek a laikusoktól abban, hogy jogi képzettségük ellenére is hajlamosak a kognitív torzításokra. ${ }^{123}$ Persze számításba kell venni, hogy a kísérletek szimulációk, így nem a való életben mért eredményekről van szó. A való életben ugyanis a bírák a kizárt bizonyítékok mellett még számos más bizonyítékot és információt mérlegelnek, ideértve az ügyvédek, ügyészek, az eljárás alá vont személy és a tanúk által elmondottakat is. Amikor azonban a bíróknak részletesebb információk állnak rendelkezésre és több idejük van mérlegelni, így alaposan megfontolni a döntést, az lehetővé teszi számukra, hogy az információkat másképp dolgozzák fel, mint a laikusok vagy az esküdtek. ${ }^{124}$ Így például, az a bíró, aki a két fél közötti közvetítést végzi, majd tárgyalásba fordul az ügy, ki tudja zárni az előzetes információt („azonban a lehorgonyzási heurisztika továbbra is hatással van rá" - említi meg Rachlinski). ${ }^{125}$ Vannak, akik szerint a bizonyítási eljárás szabályainak betartása immunissá teszi a bírákat ezekre a torzításokra. Ebben lehet valami, hiszen a bírák nemcsak ismerik, de értik is a bizonyítás szabályai mögött meghúzódó elveket, és ez nagyobb motivációt jelenthet az információ figyelmen kívül hagyása tekintetében. ${ }^{126} \mathrm{Ha}$ ebből indulunk ki, jelenthet némi különbséget a laikusok döntéshozatalától a bírák jogi képzése és tapasztalata is. ${ }^{127}$

119 VIDMAR, Neil: The Psychology of Trial Judging. Current Directions in Psychological Science, 2011/1, 3. (DOI: 10.1177/0963721410397283).

120 VIDMAR: i. m., 4.

121 WISTRICH, Andrew J.-GuthRIE, Chris-RACHLINSKI, Jeffrey J.: Can Judges Ignore Inadmissible Information? The Difficulty of Deliberately Disregarding. University of Pennsylvania Law Review, 2005/4, 1251-1345. https://scholarship.law.cornell.edu/cgi/viewcontent.cgi?article=1019\&context=Isrp_papers (2020. 04. 08.).

122 WISTRICH-GUTHRIE-RACHLINSKI: i. m., 1283.

123 VIDMAR: i. m., 4.

124 VIDMAR: i. m., 5.

125 WISTRICH-GUTHRIE-RACHLINSKI (2001): i. m., 1286.

126 WISTRICH-GUTHRIE-RACHLINSKI (2001): i. m., 1256.

127 Zenker, Frank-Dahlman, Christian-BÅAth, Rasmus-Sarwar, Farhan: Reasons Pro et Contra as a Debiasing Technique in Legal Contexts. Psychological Reports, 2018/3, 521., http://www.sumsar.net/papers/zenker_ 2018_pro_et_contra.pdf (2020.04. 07.). 
Gaeth és Shanteau tanulmányukban két, az irreleváns információ káros hatásainak csökkentését célzó képzési eljárás hatékonyságát tesztelték. ${ }^{128} \mathrm{Az}$ egyik képzés csak hagyományos frontális előadást tartalmazott, a másik interakciót és gyakorlatot. Az előzetes vizsgálat során bebizonyosodott, hogy az irreleváns információk befolyásolják az ítélethozatalt, azonban ha előadást tartanak az elme kognitív csapdáiról, az már javítja a döntések pontosságát, és az interaktív képzés az, aminek a legjelentősebb hatása van. ${ }^{129}$

\section{Zárógondolatok}

A kognitív tudományok olyan megállapításokkal élnek az emberi elme és a döntéshozatali eljárás vonatkozásában, amelyek bírósági eljárásban történő felhasználása rendkívül hasznos lehet mind a mentális állapotok pontosabb feltárása, mind a tisztességes eljárás, azon belül a befolyásmentes ítélkezésre törekvés érdekében. Annak ellenére, hogy egyelőre még vitatott a szándék, a felelősség kérdésének meghatározásában nyújtott orvosi képalkotó diagnosztikai segítség létjogosultsága, amennyiben jogi kereteit meghatározzák, egy napon mind polgári eljárásjogi, mind büntető-eljárásjogi szempontból hasznos tudást nyújthat, ezért a törekvést mindenképpen értékelni kell. Ugyanígy az idegtudományon alapuló hazugságvizsgáló berendezések - amennyiben egy napon közel 100\%-os pontossággal tudnak müködni - elmondhatatlan segítséget jelenthetnének a jogalkalmazók számára az eljárás résztvevői szavahihetőségének vizsgálatát illetően.

Számos tanulmány született a különbözö, döntéshozatalt torzító kognitív illúziókról, azonban már kevesebb az, ami kifejezetten a jogi döntéshozatalt érinti. A bírói döntéshozatalt és a kognitív illúziókat még ennél is kevesebb tanulmány vetítette egymásra (az angolszász kutatások jelentős része az esküdtek döntéshozatalát vizsgálja), a téma magyarországi ismertsége még gyerekcipőben jár. A külföldi kutatásokból mégis egyértelmüen kirajzolódik, hogy a kognitív illúziók kiküszöbölésével (elsősorban felismerésével) nagyon is megéri foglalkozni a bírói döntéshozatal vonatkozásában. Ezt elsősorban képzéssel lehetne elérni, ugyanis amennyiben a bíró tisztában van az elméje intuitív, 1. rendszerét fenyegető kognitív csapdákkal, sokkal nagyobb esélye van arra, hogy felismerje és megpróbálja kizárni azokat a döntéshozatala során.

Általános védekezési technika a különböző intuitív, kognitív reakciók ellen az alaposabb megfontolásra ösztönző jogintézmények alkalmazása és az indokolási, érvelési idő biztosítása. ${ }^{130}$ Általában az „írd ki magadból” jelenség nagyon sokat segít a torzítások enyhítésén, hiszen ami még jól hangzott az ember fejében, az később

\footnotetext{
128 GAETH, Gary J.-ShANTEAU, James: Reducing the Influence of Irrelevant Information on Experienced Decision Makers. Organizational Behavior and Human Performance, 1984/2, 263-282. http://www.sciencedirect.com/ science/article/pii/0030507384900242 (2020. 04. 08.).

129 Gaeth-Shanteau: i. m., 263.

130 PAXton, Joseph M.-Ungar, Leo-Greene, Joshua D.: Reflection and Reasoning in Moral Judgment. Cognitive Science, 2012/1, 164. https://onlinelibrary.wiley.com/doi/pdf/10.1111/j.1551-6709.2011.01210.x (2020. 04. 08.).
} 
leírva már nem mindig tünik ugyanolyan jó ötletnek. ${ }^{131}$ Ily módon a bírói döntéshozatal tekintetében a bíróság ítéletírási tevékenysége és indokolási kötelezettsége segít abban, hogy a bíró átgondolja, távolabbról szemlélje döntését és az annak meghozatalában szerepet játszó tényeket. Ezt már a Bünvádi perrendtartás idején is fontosnak tartották:

A javaslat tehát szükségesnek tartja az ítélet alapjául elfogadott tényállás indokolását, mert ez nyújt csak garantiát a bírói önkény ellen. Indokolás mellett számot kell vetni a bírónak magával és gyakran éppen az indokolás átgondolásánál veszi észre, hogy puszta sejtelem és benyomás vezetik meggyőződését, mely a szigorúbb indokolás kritikáját ki nem állja. ${ }^{132}$

Ezek alapján már a 19. században felismerték, hogy léteznek olyan döntésbefolyásoló tényezők, amelyeket alaposan végig kell gondolni a döntéshozatal és az ítéletírás során, így kizárva annak lehetőségét, hogy azok hatással legyenek magára a döntésre. Természetesen akkoriban még a mindenki számára felismerhető, nyilvánosságra kerülő, olyan általános befolyásoló tényezőket ismerték, mint például a szimpátia. A tanulmányban felvázolt, döntést torzító pszichológiai tényezők annyiban mások, hogy minden egyes embert érintenek és nem jelennek meg a külvilág felé, így kevésbé ellenőrizhetők. Éppen ezért minden bíró lelkiismeretén múlik, hogy figyelembe veszi-e a modern pszichológiai felfedezéseket döntéshozatali eljárása során.

131 WISTRICH, Andrew J.-Guthrie, Chris-RACHLINSKI, Jeffrey J.: Can Judges Ignore Inadmissible Information? The Difficulty of Deliberately Disregarding. University of Pennsylvania Law Review, 2005/4, 1251-1345. https:// scholarship.law.cornell.edu/cgi/viewcontent.cgi?article=1019\&context=lsrp_papers (2020. 04. 08.). CoHEN, Mathilde: When Judges Have Reasons Not to Give Reasons: A Comparative Law Approach. Washington and Lee Law Review, 2015/72, 483-571., https://papers.ssrn.com/sol3/papers.cfm?abstract_id=2646871 (2020. 04. 08.).

132 A bűnvádi perrendtartásról szóló 1896. évi XXXIII. törvénycikk 327. §-ához füzött indokolás. 